\author{
CZASOPISMO INŻYNIERII LAZDOWEJ, ŚRODOWISKA I ARCHITEKTURY \\ JOURNAL OF CIVIL ENGINEERING, ENVIRONMENT AND ARCHITECTURE \\ JCEEA, t. XXXI, z. 62 (3/I/15), lipiec-wrzesień 2015, s. 37-48
}

\author{
Lilianna BARTOSZEK ${ }^{1}$
}

\title{
KRĄŻENIE FOSFORU MIĘDZY WODĄ NADDENNĄ A OSADEM W EKOSYSTEMIE ZBIORNIKA ZAPOROWEGO SOLINA
}

\begin{abstract}
W pracy dokonano analizy wpływu wybranych parametrów na zawartość fosforu w wodzie interstycjalnej i kierunek jego przemieszczania się na granicy faz woda osad denny w zbiorniku zaporowym Solina. Próbki wody powierzchniowej i naddennej oraz osadów dennych pobierano z czterech stanowisk na zbiorniku solińskim w okresie wegetacyjnym w latach 2005-2006. Do analizy frakcjonowania fosforu w osadach zastosowano metodę SMT. Wyższe stężenia form fosforu, żelaza i manganu oraz wysoki stosunek Fe/P stwierdzono w strefie wody naddennej w porównaniu do powierzchniowej. W wodzie interstycjalnej osadów zbiornika Solina występowały stosunkowo niskie stężenia fosforu mineralnego. Duża ich zmienność i rozpiętość była związana z mniejszym uwodnieniem osadów, utrudniającym proces dyfuzji fosforanów. Średnia zawartość fosforu mineralnego w wodzie interstycjalnej osadów zbiornika Solina kształtowała się na poziomie odpowiadającym jeziorom oligotroficznym. Dobre natlenienie panujące przez cały okres badawczy oraz żelazo obecne w dużych stężeniach, jak również wysoki stosunek Fe/P w wodzie naddennej stwarzały bardzo sprzyjające warunki do wytrącania i depozycji fosforanów w osadach, a nie do jego uwalniania. Osady denne zbiornika Solina charakteryzowały się stosunkowo niską zawartością fosforu, a wysoką zawartością żelaza i manganu, oraz wysokim stosunkiem Fe/P, które determinują trwałość połączeń Fe-P i Mn-P w mniej korzystnych warunkach oksydacyjno - redukcyjnych. W podpowierzchniowych warstwach osadów dennych zawartość fosforu mineralnego w odtlenianej okresowo wodzie interstycjalnej w istotny sposób zależała od zawartości żelaza i manganu w depozytach.
\end{abstract}

Słowa kluczowe: fosfor mineralny, woda naddenna, interstycjalna, osady denne, frakcje fosforu

\section{Wprowadzenie}

Stężenie fosforu w wodzie zbiornika zaporowego zależy od tego, jaka jego ilość zostanie doprowadzona ze źródeł zewnętrznych, jaka odprowadzona wraz $\mathrm{z}$ odpływem, wyniesiona z migrującymi organizmami oraz ulegnie sedymentacji do osadów dennych.

${ }^{1}$ Lilianna Bartoszek, Politechnika Rzeszowska, al. Powstańców Warszawy 12, 35-959 Rzeszów, tel.: 17865 1278, bartom@prz.edu.pl 
Do źródeł zewnętrznych zanieczyszczenia wód zbiorników zaporowych związkami fosforu zalicza się ścieki, zwłaszcza bytowo-gospodarcze ze zlewni bezpośredniej, wody dopływów zasilających obiekt, spływ powierzchniowy wód opadowych $\mathrm{z}$ terenów użytkowanych rolniczo, a także wietrzenie i rozpuszczanie przez wody opadowe minerałów fosforanowych znajdujących się w glebie oraz opady atmosferyczne [1, 4].

Fosfor w postaci fosforanów jest pobierany przez glony, bakterie oraz makrofity i kumulowany $w$ ich organizmach przez cały okres wegetacyjny. W głębokich zbiornikach zaporowych o charakterze limnicznym głównym procesem wycofywania fosforu $\mathrm{z}$ obiegu biologicznego może być jego sedymentacja do osadów dennych w postaci trudno rozpuszczalnych połączeń nieorganicznych, nieorganiczno-organicznych $\mathrm{w}$ trakcie lata, a także obumarłych szczątków roślinnych i zwierzęcych po zakończeniu sezonu wegetacyjnego. Nagromadzenie się materii organicznej w osadach dennych może prowadzić wskutek jej tlenowego rozkładu do wystąpienia okresowego deficytu tlenu w wodzie naddennej, a w zbiornikach silnie eutroficznych do zastąpienia tlenowego bakteryjnego metabolizmu przez beztlenową fermentację.

Procesy rozkładu materii organicznej przy jej dużym nagromadzeniu w osadach zachodzą bardzo intensywnie, co prowadzi do powstawania znacznych ilości produktów jej rozkładu, w tym też soli mineralnych rozpuszczonych w wodzie interstycjalnej pomiędzy cząstkami osadu [7, 9].

W wyniku rozkładu materii organicznej również fosforany mogą wracać do toni wodnej i nasilać w niej proces eutrofizacji.

Nie tylko substancje organiczne nie są na stałe deponowane w osadach dennych zbiorników wodnych. Także połączenia nieorganiczne fosforu mogą ulegać rozkładowi w zmiennych warunkach oksydacyjno-redukcyjnych, temperatury, $\mathrm{pH}$ i zasilać wody zbiornika w fosforany. Trwałość depozycji fosforu w osadach zależy przede wszystkim od charakteru połączeń chemicznych, w jakich w nich występuje.

Krążenie fosforu w ekosystemie wodnym odgrywa znaczącą rolę w procesie eutrofizacji. Intensywny przepływ fosforu $\mathrm{z}$ osadów dennych do wody w sytuacji ograniczenia jego dopływu ze źródeł zewnętrznych zniweczył efekty wprowadzenia działań ochronnych na terenie zlewni wielu zbiorników wodnych, gdzie nie tylko nie uzyskano oczekiwanej poprawy jakości wody, ale nawet zahamowania procesu eutrofizacji.

Osady zbiorników silnie eutroficznych mogą wprowadzać do wody naddennej ładunek fosforanów na poziomie porównywalnym do źródła zewnętrznego $[6,16]$.

Celem pracy była analiza wpływu wybranych parametrów na zawartość fosforu w wodzie interstycjalnej i kierunek jego przemieszczania się na granicy faz woda - osad denny w zbiorniku zaporowym Solina. 


\section{Teren badań i metodyka}

\section{Teren badań}

Zbiornik Solina to najgłębszy, a dzięki temu największy pod względem pojemności zbiornik zaporowy w Polsce (tab. 1.). Wraz z położonym niżej zbiornikiem wyrównawczym Myczkowce wchodzi w skład Zespołu Elektrowni Wodnych Solina - Myczkowce S.A. Zlewnia zbiornika Solina posiada górski charakter, jest w przeważającej części pokryta lasami $(>75 \%)$ i w kilkunastu procentach (14\%) użytkami zielonymi, co pozwala zaszeregować ją do pastwiskowo-leśnych. Obszar zlewni jest w małym stopniu zaludniony, nie występują tam zakłady przemysłowe uciążliwe dla środowiska. Zabudowania osadnicze, a także infrastruktura rekreacyjno-turystyczna zlokalizowane są przede wszystkim w zlewni bezpośredniej wokół zbiornika oraz w dolinach przyujściowych rzek i potoków. $\mathrm{Na}$ terenie zlewni dominują gleby gliniaste z domieszką piasku, żwiru i kamieni, które w umiarkowany sposób sprzyjają wymywaniu substancji $[3,11,12,14]$.

Tabela 1. Parametry morfometryczne zbiornika zaporowego Solina, na podstawie [9]

Table 1. Morphometric parameters of the Solina Reservoir, based on [9]

\begin{tabular}{|c|c|}
\hline Parametr & Zbiornik Solina \\
\hline Powierzchnia [ha] & 2200 \\
\hline Objętość maksymalna [mln $\left.\mathrm{m}^{3}\right]$ & 502 \\
\hline Głębokość średnia $(\mathrm{maks})[\mathrm{m}]$ & $22(60)$ \\
\hline Powierzchnia zlewni $\left[\mathrm{km}^{2}\right]$ & 1174,5 \\
\hline Czas zatrzymania wody $[\mathrm{d}]$ & $155-273$ \\
\hline
\end{tabular}

\section{Metodyka badań}

Próbki wody i osadów dennych pobierano z czterech stanowisk na zbiorniku solińskim (rys. 1.): 1. Centralny, 2. Zapora, 3. Brama, 4. Skałki, (śr. głęb. ok. $45,60,14,15 \mathrm{~m}$ odpowiednio) 1-2 razy w miesiącu od maja do listopada $2005 \mathrm{r}$ (9 próbek) i 1 raz w miesiącu od kwietnia (oprócz maja) do listopada 2006r (7 próbek). Próbki wody czerpano z głębokości ok. $0,5 \mathrm{~m}$ pod powierzchnią oraz ok. $1 \mathrm{~m}$ nad osadem (czerpak Ruttnera). Pomiary zawartości tlenu rozpuszczonego i pH przeprowadzono przy pomocy wieloparametrowego miernika MultiLine P4 (WTW Germany) z sondą tlenową CellOx 325 (tlen - $\mathrm{O}_{2}$ ), elektrodą kombinowaną Sen Tix 61 (odczyn - pH).

Do analiz pobierano wierzchnią $0-5 \mathrm{~cm}$ warstwę osadów uśrednioną $\mathrm{z}$ trzech rdzeni. Wodę interstycjalną oddzielono poprzez odwirowanie (przy $4000 \mathrm{obr} . / \mathrm{min}$ ). Do analizy frakcjonowania fosforu w osadach zastosowano metodę SMT [10, 13]. Uzyskano frakcje: nieorganiczny fosfor (IP), organiczny fosfor (OP), apatytowy fosfor (AP, formy związane $\mathrm{z}$ wapniem) i nieapatytowy, nieorganiczny fosfor (NAIP, formy związane z tlenkami i wodorotlenkami Al, Fe i $\mathrm{Mn}$ ). Osady denne mineralizowano w stężonym kwasie $\mathrm{HNO}_{3}$ (mineralizacja mikrofalowa 2-4.5 MPa - UniClever II Plazmatronika). 


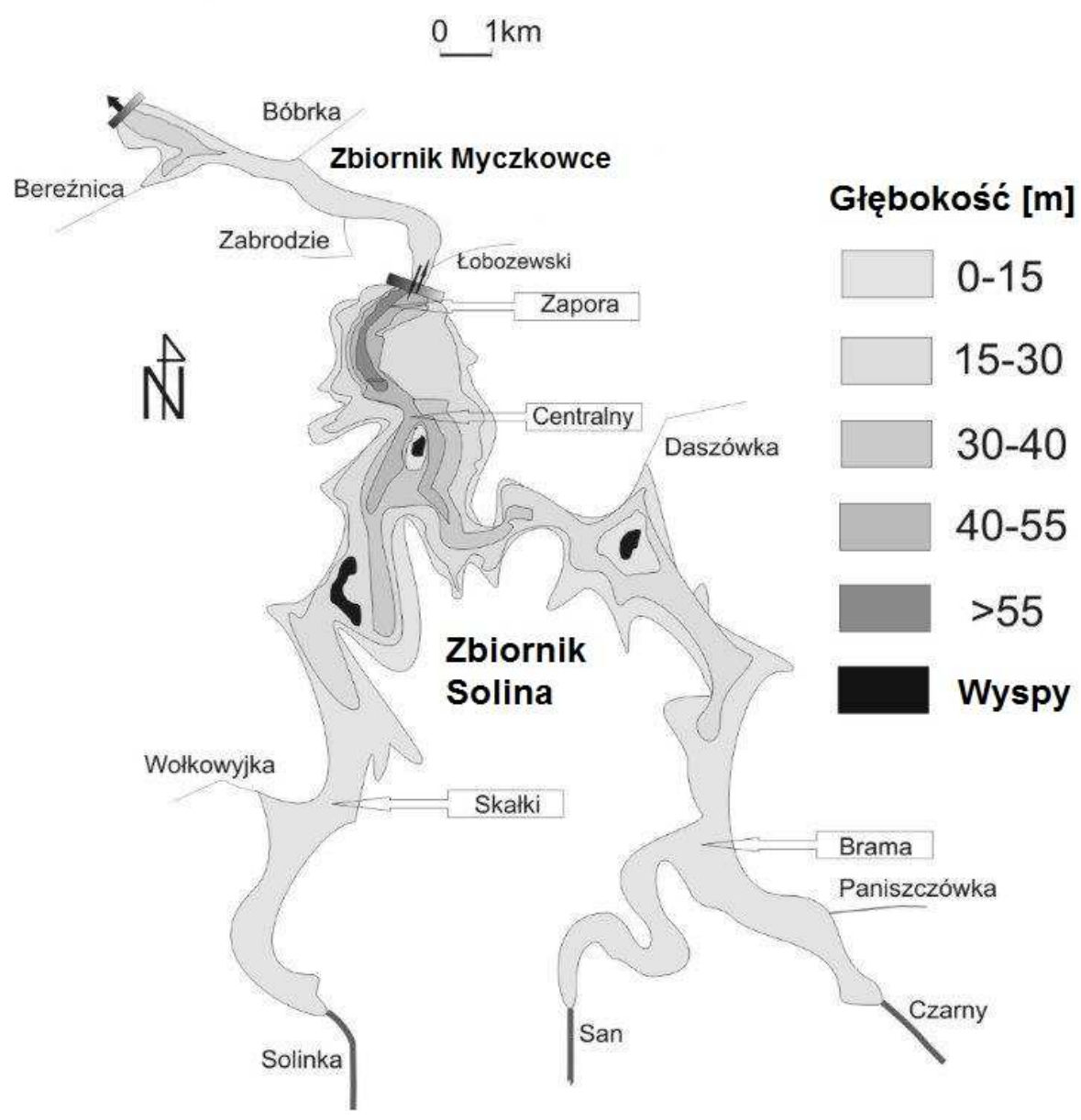

Rys. 1. Zespół zbiorników zaporowych Solina-Myczkowce - rozmieszczenie stanowisk badawczych. Źródło: Opracowanie własne

Fig. 1. The complex of the Solina-Myczkowce reservoirs - the distribution of research positions. Reference: Own study

Analizy form fosforu w wodzie, ekstraktach i mineralizatach osadów dennych wykonano metodą spektrofotometryczną. Do oznaczeń spektrofotometrycznych wykorzystano spektrofotometr Aquamate (Thermo Spectronic, United Kingdom). Fosfor całkowity, żelazo, glin i mangan w mineralizatach osadów również analizowano spektrofotometrycznie. Zawartość wapnia oznaczano techniką AAS (Perkin Elmer, AAnalyst 300). Wysuszone osady wyprażano w temp. $550{ }^{\circ} \mathrm{C}$ przez $4 \mathrm{~h}$ w celu obliczenia zawartości materii organicznej (OM). Wpływ wybranych parametrów na zawartość fosforu w wodzie interstycjalnej i osadach dennych oceniano za pomocą analizy regresji prostej przy zadanym poziomie istotności $\alpha=0,05$ [15]. 


\section{Wyniki i dyskusja}

\section{Fosfor w wodzie powierzchniowej i naddennej}

W analizowanym okresie badań zawartość fosforu fosforanowego w wodach powierzchniowych zbiornika solińskiego wahała się od 0,01 do 0,09 mgP $\mathrm{dm}^{-3}$ (tab. 2.). Fosfor ogólny kształtował się od 0,02 do $0,19 \mathrm{mgP} \mathrm{dm}{ }^{-3}$. Zawartość fosforu $\mathrm{w}$ wodach zbiornika była dość zróżnicowana, wyraźnie wyższe stężenia fosforu ogólnego od września świadczą o zakończeniu sezonu wegetacyjnego. Wyższe stężenia fosforu ogólnego na stanowisku Brama już w okresie lata były związane $\mathrm{z}$ większymi ładunkami fosforu dostarczanymi przez dwa większe i bardziej zanieczyszczone w związki biogenne dopływy San i Czarny [2]. Fosfor mineralny stanowił średnio $42 \%$ puli fosforu ogólnego i wahał się w analizowanym okresie od 7,7\% do $100 \%$.

Tabela 2. Zakres stężeń wybranych parametrów w wodzie powierzchniowej i naddennej zbiornika Solina

Table 2. The range of selected parameters concentrations in surface and overlying water of the Solina Reservoir

\begin{tabular}{|l|l|l|l|l|l|}
\hline Parametr & Zapora & Centralny & Brama & Skałki \\
\hline \multicolumn{7}{|c|}{ Woda powierzchniowa } \\
\hline${\mathrm{P}-\mathrm{PO}_{4}{ }^{3-}}^{3-}\left[\mathrm{mgP} \mathrm{dm}^{-3}\right]$ & $0,01-0,05$ & $0,01-0,09$ & $0,01-0,09$ & $0,01-0,07$ \\
\hline $\mathrm{P}_{\text {og. }}$ & {$\left[\mathrm{mgP} \mathrm{dm}^{-3}\right]$} & $0,02-0,09$ & $0,02-0,12$ & $0,03-0,19$ & $0,02-0,14$ \\
\hline $\mathrm{Fe}$ & {$\left[\mathrm{mg} \mathrm{dm}^{-3}\right]$} & $0,04-0,45$ & $0,05-0,41$ & $0,06-0,61$ & $0,06-0,33$ \\
\hline $\mathrm{Mn}$ & {$\left[\mathrm{mg} \mathrm{dm}^{-3}\right]$} & $0,05-0,25$ & $0,04-0,25$ & $0,10-0,32$ & $0,10-0,26$ \\
\hline $\mathrm{Fe} / \mathrm{P}$ & & $0,4-11,3$ & $0,4-8,2$ & $0,5-10,2$ & $0,5-8,3$ \\
\hline \multicolumn{7}{|c|}{ Woda naddenna } \\
\hline $\mathrm{Fe}$ & {$\left[\mathrm{mg} \mathrm{dm}^{-3}\right]$} & $0,84-3,30$ & $0,97-4,89$ & $0,88-4,99$ & $0,72-2,45$ \\
\hline $\mathrm{Mn}$ & {$\left[\mathrm{mg} \mathrm{dm}^{-3}\right]$} & $0,09-0,29$ & $0,09-0,62$ & $0,11-0,59$ & $0,11-0,72$ \\
\hline $\mathrm{Fe} / \mathrm{P}$ & & $4,7-46,0$ & $8,9-36,8$ & $8,0-44,0$ & $7,2-39,2$ \\
\hline
\end{tabular}

Wyższe stężenia form fosforu, żelaza i manganu oraz wysoki stosunek $\mathrm{Fe} / \mathrm{P}$ stwierdzono w strefie wody naddennej w porównaniu do powierzchniowej. Znacznie wyższe stężenia fosforu ogólnego $\left(0,03-0,29 \mathrm{mgP} \mathrm{dm}^{-3}\right)$ w stosunku do fosforu mineralnego $\left(0,01-0,12 \mathrm{mgP} \mathrm{dm}^{-3}\right)$ w wodzie naddennej były związane $\mathrm{z}$ sedymentacją fosforu zawiesinowego i być może $\mathrm{z}$ resuspensją osadów dennych. W całym okresie badań natlenienie wód powierzchniowych było dobre (od 7,71 do $10,66 \mathrm{mgO}_{2} \mathrm{dm}^{-3}$ ). W warstwach przydennych zbiornika solińskiego zawartość tlenu rozpuszczonego w wodzie była niższa i wahała się od 4,43 do 7,85 $\mathrm{mgO}_{2} \mathrm{dm}^{-3}$. Mimo to strefa naddenna przez cały okres badawczy charakteryzowała się dość dobrym natlenieniem. Odczyn wód w całym okresie badawczym pozostawał obojętny do lekko zasadowego (7,53 - 9,03 woda powierzchniowa; 7,50 - 8,22 woda naddenna). 


\section{Fosfor w osadach dennych}

Osady denne pobrane $\mathrm{z}$ różnych stref zbiornika różniły się między sobą stopniem uwodnienia. W strefie jeziornej były muliste i bardziej uwodnione (Centralny - ok. 68,6\% i Zapora - ok. 72,1\%) (tab. 3.).

W strefach wpływów rzecznych depozyty były mniej uwodnione (Brama ok. 64,5\% i Skałki - ok. 58,9\%), miały konsystencję bardziej zwartą. Osady pobrane na stanowisku Brama były muliste, mocno skonsolidowane, na stanowisku Skałki piaszczysto-muliste.

Osady denne ze wszystkich stanowisk zawierały znaczne ilości żelaza, glinu i manganu, a stosunkowo niewielkie ilości fosforu, wapnia oraz materii organicznej (tab. 3.).

Tabela 3. Średnie zawartości wybranych parametrów w osadach dennych zbiornika zaporowego Solina (średnia \pm S.D.)

Table 3. Average contents of selected parameters in the bottom sediments of the Solina Reservoir (mean $\pm \mathrm{SD})$

\begin{tabular}{|c|c|c|c|c|c|}
\hline Parametr & & $\begin{array}{l}\text { Zapora } \\
\mathrm{n}=15\end{array}$ & $\begin{array}{l}\text { Centralny } \\
\mathrm{n}=16\end{array}$ & $\begin{array}{l}\text { Brama } \\
\mathrm{n}=16\end{array}$ & $\begin{array}{l}\text { Skałki } \\
\mathrm{n}=16\end{array}$ \\
\hline $\mathrm{P}_{\text {calk. }}$ & \multirow{5}{*}[\mathrm{mg}\mathrm{g}^{-1}\text{s.m.o.}]{} & $0,93 \pm 0,05$ & $0,91 \pm 0,05$ & $0,86 \pm 0,05$ & $0,69 \pm 0,02$ \\
\hline $\mathrm{Fe}$ & & $45,6 \pm 2,1$ & $44,6 \pm 5,7$ & $43,3 \pm 2,7$ & $39,8 \pm 2,5$ \\
\hline $\mathrm{Mn}$ & & $3,05 \pm 0,79$ & $2,82 \pm 1,07$ & $2,10 \pm 0,47$ & $1,66 \pm 0,34$ \\
\hline $\mathrm{Al}$ & & $39,9 \pm 3,8$ & $40,5 \pm 4,5$ & $38,9 \pm 4,9$ & $35,8 \pm 2,6$ \\
\hline $\mathrm{Ca}$ & & $5,56 \pm 1,6$ & $7,67 \pm 1,48$ & $11,96 \pm 3,3$ & $14,25 \pm 3,4$ \\
\hline $\mathrm{Fe} / \mathrm{P}$ & & $49,1 \pm 2,6$ & $49,0 \pm 6,1$ & $50,6 \pm 2,4$ & $57,8 \pm 4,5$ \\
\hline $\mathrm{OM}$ & \multirow{2}{*}[\%]{} & $8,48 \pm 0,94$ & $8,86 \pm 0,6$ & $8,81 \pm 0,56$ & $8,19 \pm 0,5$ \\
\hline $\mathrm{W}_{\mathrm{o}}$ & & $72,1 \pm 2,8$ & $68,6 \pm 6,7$ & $64,5 \pm 3,9$ & $58,9 \pm 1,7$ \\
\hline NAIP & \multirow{3}{*}[\mathrm{mg}\mathrm{g}^{-1}\text{s.m.o.}]{} & $0,263 \pm 0,03$ & $0,237 \pm 0,03$ & $0,196 \pm 0,02$ & $0,126 \pm 0,02$ \\
\hline OP & & $0,323 \pm 0,02$ & $0,320 \pm 0,03$ & $0,291 \pm 0,03$ & $0,218 \pm 0,02$ \\
\hline $\mathrm{AP}$ & & $0,320 \pm 0,06$ & $0,320 \pm 0,05$ & $0,339 \pm 0,03$ & $0,306 \pm 0,02$ \\
\hline
\end{tabular}

Średnia zawartość frakcji NAIP (odzwierciedlająca połączenia fosforu z żelazem, manganem i glinem) była najniższa w osadach na wszystkich stanowiskach spośród wszystkich trzech frakcji i zwiększała się wraz ze wzrostem średniej zawartości żelaza i manganu w osadach. Analogiczną, choć nieznaczną tendencję wzrostową wykazała średnia zawartość fosforu całkowitego. Natomiast średni stosunek Fe/P nieznacznie wzrastał wraz ze spadkiem zawartości żelaza i fosforu w osadach.

\section{Fosfor w wodzie interstycjalnej}

Procesy rozkładu materii organicznej intensywnie zachodzące w osadach dennych mogą spowodować, że pod ich powierzchnią nawet przy dobrym natlenieniu wody naddennej będą panować warunki beztlenowe. W związku 
z tym, w odtlenionej wodzie interstycjalnej osadów zbiorników eutroficznych mogą występować wysokie stężenia fosforu mineralnego. Stężenia fosforanów w wodzie interstycjalnej i naddennej są rozpatrywane jako wskaźniki intensywności przemieszczania się fosforu na granicy faz woda - osad [8].

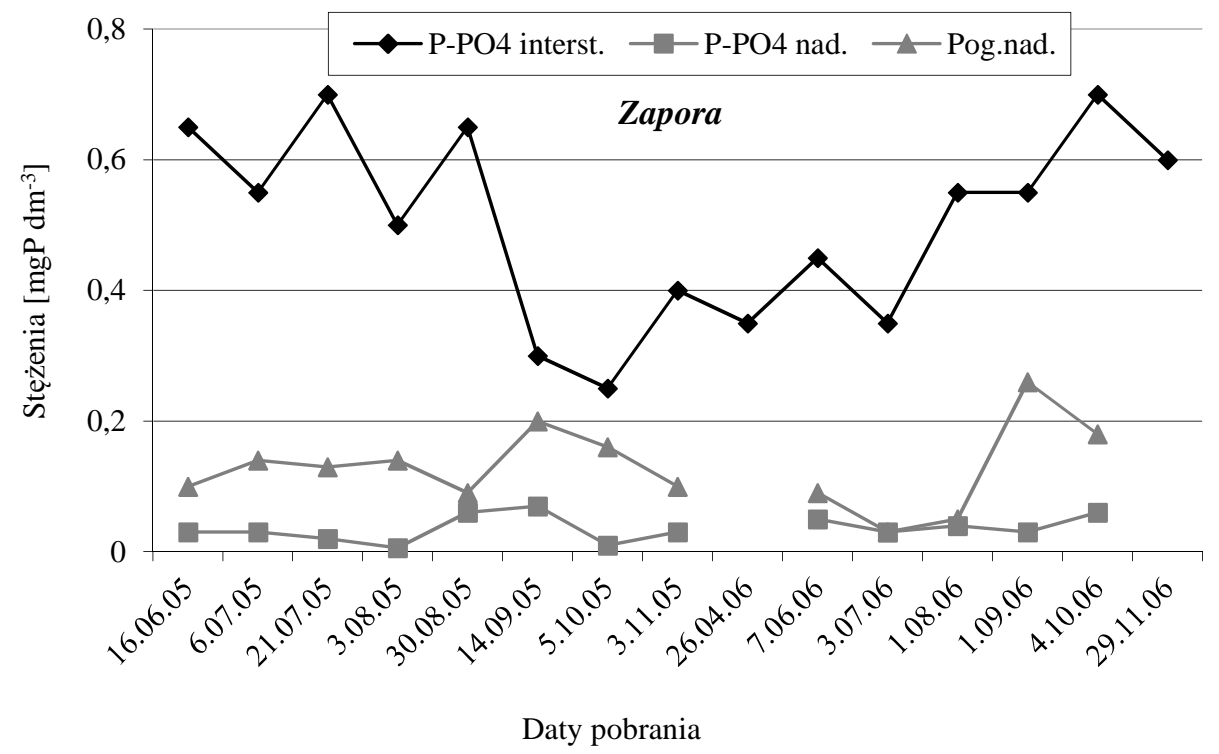

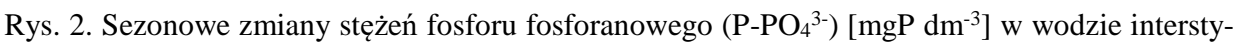

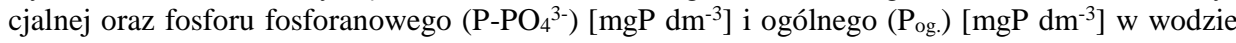
naddennej na stanowisku Zapora

Fig. 2. Seasonal changes in concentrations of mineral phosphorus $\left(\mathrm{P}_{-} \mathrm{PO}_{4}{ }^{3-}\right)\left[\mathrm{mgP} \mathrm{dm}^{-3}\right]$ in the

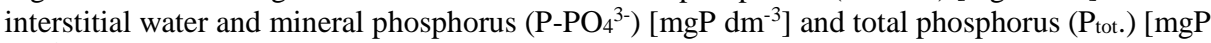
$\left.\mathrm{dm}^{-3}\right]$ in the overlying water for Zapora station

Zakres stężeń fosforu fosforanowego w wodzie interstycjalnej uzyskanej z osadów zbiornika solińskiego wahał się od 0,10 do $1,60 \mathrm{mgP} \mathrm{dm}^{-3}$ (rys. 2.-5.) (średnia $0,60 \mathrm{mgP} \mathrm{dm}^{-3}$ ). Podczas gdy, stężenia fosforu ogólnego w wodzie naddennej zbiornika solińskiego $\mathrm{w}$ analizowanym okresie wynosiły od 0,03 do $0,29 \mathrm{mgP} \mathrm{dm}^{-3}$. Przykładowo, stężenia fosforu mineralnego odnotowane $\mathrm{z}$ wodzie interstycjalnej zbiorników eutroficznych wahały się od 0,52 do 3,50 mgP $\mathrm{dm}^{-3}$, zbiorników hypertroficznych od 0,92 do nawet $13,20 \mathrm{mgP} \mathrm{dm}^{-3}$ [18]. W jeziorze Gościąż stwierdzono bardzo duży zakres stężeń fosforu fosforanowego w wodzie interstycjalnej od 0,12 do $10,47 \mathrm{mgP} \mathrm{dm}^{-3}$. Najwyższe wartości notowano najczęściej w miesiącach letnich [8]. Gonsiorczyk i inni [5] podają, że średnie stężenie fosforu mineralnego wynosiło 0,52 oraz $2,94 \mathrm{mgP} \mathrm{dm}^{-3}$ w wodzie interstycjalnej jeziora oligotroficznego i eutroficznego (odpowiednio). 


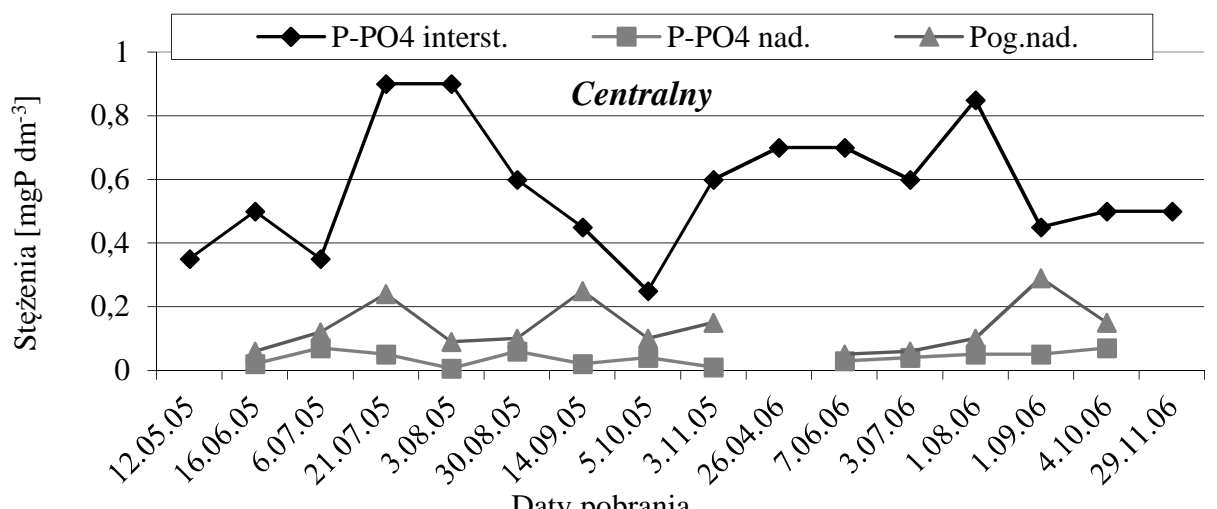

Rys. 3. Sezonowe zmiany stężeń fosforu fosforanowego $\left(\mathrm{P}_{-} \mathrm{PO}_{4}{ }^{3-}\right)\left[\mathrm{mgP} \mathrm{dm}^{-3}\right]$ w wodzie intersty-

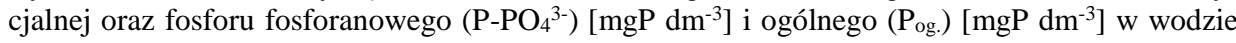
naddennej na stanowisku Centralny

Fig. 3. Seasonal changes in concentrations of mineral phosphorus $\left(\mathrm{P}^{-} \mathrm{PO}_{4}{ }^{3-}\right)\left[\mathrm{mgP} \mathrm{dm}^{-3}\right]$ in the

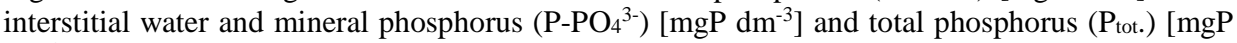
$\left.\mathrm{dm}^{-3}\right]$ in the overlying water for Centralny station

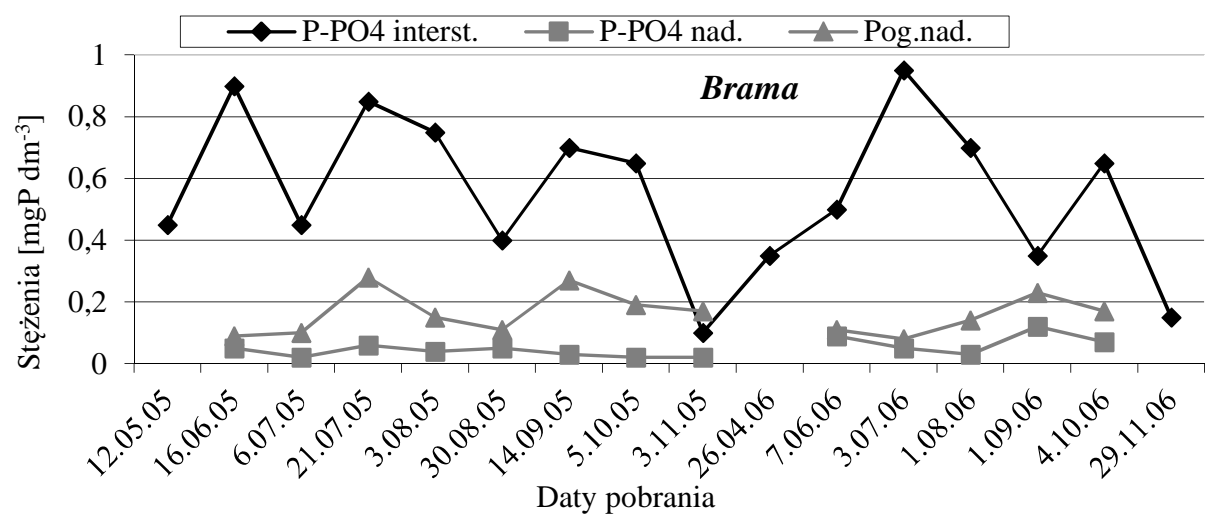

Rys. 4. Sezonowe zmiany stężeń fosforu fosforanowego $\left(\mathrm{P}_{-} \mathrm{PO}_{4}{ }^{3-}\right)\left[\mathrm{mgP} \mathrm{dm}^{-3}\right]$ w wodzie interstycjalnej oraz fosforu fosforanowego $\left(\mathrm{P}^{-\mathrm{PO}_{4}}{ }^{3-}\right)\left[\mathrm{mgP} \mathrm{dm}^{-3}\right]$ i ogólnego $\left(\mathrm{Pog}\right.$.) $\left[\mathrm{mgP} \mathrm{dm}^{-3}\right] \mathrm{w}$ wodzie naddennej na stanowisku Brama

Fig. 4. Seasonal changes in concentrations of mineral phosphorus $\left(\mathrm{P}_{-} \mathrm{PO}_{4}{ }^{3-}\right)\left[\mathrm{mgP} \mathrm{dm}^{-3}\right]$ in the interstitial water and mineral phosphorus $\left(\mathrm{P}^{\left.-\mathrm{PO}_{4}{ }^{3-}\right)}\left[\mathrm{mgP} \mathrm{dm}^{-3}\right]\right.$ and total phosphorus $\left(\mathrm{P}_{\text {tot. }}\right)[\mathrm{mgP}$ $\left.\mathrm{dm}^{-3}\right]$ in the overlying water for Brama station

Dużą zmienność i rozpiętość stężeń fosforu fosforanowego w wodzie interstycjalnej zaobserwowano na stanowiskach: Skałki i Brama (rys. 4.-5.). Różnica stężeń między wodą naddenną a interstycjalną powoduje przechodzenie fosforanów z osadów dennych do wód naddennych lub odwrotnie. Im mniejsze uwodnienie osadów, tym trudniej zachodził proces dyfuzji fosforu fosforanowego, co wyraźnie widać po dużej zmienności fosforu mineralnego w wodzie intersty- 


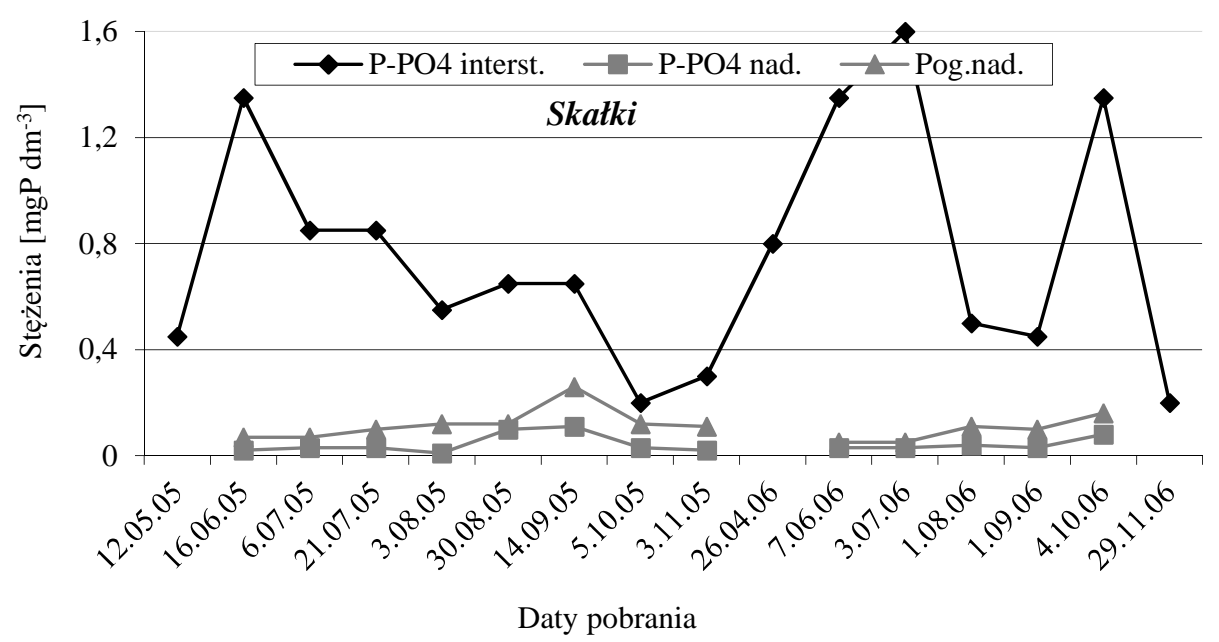

Rys. 5. Sezonowe zmiany stężeń fosforu fosforanowego $\left(\mathrm{P}_{-} \mathrm{PO}_{4}{ }^{3-}\right)\left[\mathrm{mgP} \mathrm{dm}^{-3}\right] \mathrm{w}$ wodzie interstycjalnej oraz fosforu fosforanowego $\left(\mathrm{P}_{-} \mathrm{PO}_{4}{ }^{3-}\right)\left[\mathrm{mgP} \mathrm{dm}^{-3}\right]$ i ogólnego $\left(\mathrm{Pog}_{\mathrm{og}}\right)\left[\mathrm{mgP} \mathrm{dm}^{-3}\right] \mathrm{w}$ wodzie naddennej na stanowisku Skałki

Fig. 5. Seasonal changes in concentrations of mineral phosphorus $\left(\mathrm{P}_{-} \mathrm{PO}_{4}{ }^{3-}\right)\left[\mathrm{mgP} \mathrm{dm}{ }^{-3}\right]$ in the interstitial water and mineral phosphorus $\left(\mathrm{P}_{-} \mathrm{PO}_{4}{ }^{3-}\right)\left[\mathrm{mgP} \mathrm{dm}^{-3}\right]$ and total phosphorus $\left(\mathrm{P}_{\text {tot. }}\right)[\mathrm{mgP}$ $\mathrm{dm}^{-3}$ ] in the overlying water for Skałki station

cjalnej na stanowisku Skałki (od 0,20 do 1,60 $\mathrm{mgP} \mathrm{dm}^{-3}$ ). Osady na stanowisku Brama były również bardziej skonsolidowane, lepkie, co także mogło utrudniać proces dyfuzji fosforanów z wody interstycjalnej do wody naddennej i odwrotnie, przemieszczanie się fosforu w głąb osadów. Ogólnie, zaobserwowano nieznaczne i nieregularne podwyższenie stężeń fosforu mineralnego w wodzie interstycjalnej latem.

Żelazo stwierdzone w dużych stężeniach w wodzie naddennej (w zakresie od 0,72 do $4,99 \mathrm{mg} \mathrm{dm}^{-3}$ ) w okresie stratyfikacji w zbiorniku solińskim pełniło rolę bariery ochronnej, zatrzymując w warunkach dobrego natlenienia dyfundujący fosfor mineralny $\mathrm{z}$ wody interstycjalnej do wody naddennej, powodując jego ponowną sorpcję i deponowanie w osadach dennych. Stosunek Fe/P w wodzie naddennej zbiornika solińskiego w analizowanym okresie obejmował zakres od 4,7 do 46,0, podczas gdy, samoistne wytrącanie fosforanów w hypolimnionie zachodzi już gdy stosunek Fe/P jest wyższy od 3,0 [17].

Nie stwierdzono statystycznie istotnych zależności pomiędzy zawartością fosforu fosforanowego w wodzie interstycjalnej osadów dennych a stężeniem parametrów mierzonych w wodzie badanego zbiornika. Zaobserwowano natomiast nieznaczne, ale statystycznie istotne, ujemne korelacje pomiędzy stężeniami fosforu fosforanowego $\mathrm{w}$ wodzie interstycjalnej a zawartością żelaza i manganu w osadach dennych (tab. 4.). Te ujemne korelacje sugerują, że im wyższa zawartość żelaza oraz manganu w osadach tym, na skutek wiązania fosforu w depozytach, obniżeniu ulegało stężenie fosforu mineralnego w wodzie interstycjalnej. Obserwowane zmiany w stężeniach fosforu mineralnego 
Tabela 4. Wpływ wybranych parametrów na stężenie fosforu fosforanowego (P-PO $\left.{ }^{3-}\right)\left[\mathrm{mgP} \mathrm{dm}^{-3}\right]$ w wodzie interstycjalnej oraz zależność zawartości fosforu w osadach od zmienności jego poszczególnych form

Table 4. The influence of selected parameters on the concentration of mineral phosphorus (P$\left.\mathrm{PO}_{4}^{3-}\right)\left[\mathrm{mgP} \mathrm{dm}^{-3}\right]$ in the interstitial water and the dependence of phosphorus in the sediments on the variability of its individual forms

\begin{tabular}{|c|c|c|c|c|}
\hline $\mathbf{y}$ & $\mathbf{f}(\mathbf{x})$ & $\begin{array}{l}\text { Współczynnik } \\
\text { korelacji (R) }\end{array}$ & $\mathbf{N}$ & $\begin{array}{l}\text { Poziom } \\
\text { istotności }\end{array}$ \\
\hline \multirow{6}{*}{$\begin{array}{c}\mathrm{P}-\mathrm{PO}_{4}{ }^{3-} \\
\text { interstycjalna }\end{array}$} & $\mathrm{Fe}$ & $-0,34$ & \multirow{11}{*}{63} & $<0,01$ \\
\hline & $\mathrm{Mn}$ & $-0,33$ & & $<0,01$ \\
\hline & $\mathrm{P}_{\text {całk. }}$ & $-0,35$ & & $<0,01$ \\
\hline & NAIP & $-0,33$ & & $<0,01$ \\
\hline & OP & $-0,26$ & & $<0,05$ \\
\hline & $\mathrm{W}_{\mathrm{o}}$ & $-0,34$ & & $<0,01$ \\
\hline \multirow{4}{*}{$\mathrm{P}_{\text {całk }}$} & Wo & 0,74 & & $<0,001$ \\
\hline & NAIP & 0,87 & & $<0,001$ \\
\hline & OP & 0,85 & & $<0,001$ \\
\hline & AP & 0,34 & & $<0,01$ \\
\hline OP & NAIP & 0,86 & & $<0,001$ \\
\hline
\end{tabular}

w wodzie interstycjalnej wykazały istotną, ujemną zależność od zmian zawartości fosforu całkowitego, frakcji NAIP i OP oraz zawartości wody w osadach. Im mniejsze uwodnienie depozytów, tym transport dyfuzyjny fosforu stawał się trudniejszy i stąd wyższe stężenia fosforu fosforanowego w wodzie interstycjalnej oraz niższe zawartości jego form w osadach.W osadach dennych jeziora Gościąż stwierdzono dodatnią zależność pomiędzy stężeniem fosforu mineralnego w wodzie interstycjalnej a zawartością fosforu całkowitego [8]. Frakcje NAIP i OP odzwierciedlające zawartość mobilnych form fosforu wykazały bardzo duży wpływ na zmienność stężeń fosforu całkowitego w osadach (wysokie współczynniki korelacji). Fosfor związany z wapniem (AP) wykazał niewielki wpływ na wahania zawartości fosforu całkowitego w depozytach zbiornika solińskiego. Świadczy to o małej mobilności fosforu apatytowego i pokazuje, że udział tego typu połączeń w procesach uwalniania lub bezpośredniej retencji fosforu w osadach zbiornika Solina jest nieznaczny, pomimo stosunkowo dużej zawartości tej frakcji. Zaobserwowana, istotna, dodatnia korelacja pomiędzy zawartością frakcji OP i NAIP w depozytach sugeruje, że część fosforu w połączeniach organicznych mogła występować w formie związków kompleksowych z żelazem, manganem lub glinem (np. mało mobilnych kompleksów żelazowo - fosforowo - humusowych itd.).

\section{Podsumowanie i wnioski}

W wodzie interstycjalnej osadów zbiornika Solina występowały stosunkowo niskie stężenia fosforu mineralnego. Duża ich zmienność i rozpiętość była związana z mniejszym uwodnieniem osadów, utrudniającym proces dyfuzji fosforanów. 
Średnia zawartość fosforu mineralnego w wodzie interstycjalnej osadów zbiornika Solina kształtowała się na poziomie odpowiadającym jeziorom oligotroficznym.

Dobre natlenienie panujące przez cały okres badawczy oraz żelazo obecne w dużych stężeniach, jak również wysoki stosunek Fe/P w wodzie naddennej stwarzały bardzo sprzyjające warunki do wytrącania i depozycji fosforanów w osadach, a nie do jego uwalniania.

Osady denne zbiornika Solina charakteryzowały się stosunkowo niską zawartością fosforu, a wysoką zawartością żelaza i manganu, oraz wysokim stosunkiem Fe/P, które determinują trwałość połączeń Fe-P i Mn-P w mniej korzystnych warunkach oksydacyjno - redukcyjnych.

W podpowierzchniowych warstwach osadów dennych zawartość fosforu mineralnego w odtlenianej wodzie interstycjalnej w istotny sposób zależała od zawartości żelaza i manganu w depozytach.

Badania dofinansowane przez Ministerstwo Nauki i Szkolnictwa Wyższego w ramach projektów badawczych 2 PO4G 08427 i N523 009 32/0288.

\section{Literatura}

[1] Bajkiewicz-Grabowska E.: Obieg materii w systemach rzeczno-jeziornych. Uniwersytet Warszawski, Wydział Geografii i Studiów Regionalnych, Warszawa 2002.

[2] Bartoszek L., Koszelnik P., Tomaszek J.: Dynamika zmian fosforu w dopływach zbiornika solińskiego. I Kongres Inżynierii Środowiska, Monografie Komitetu Inżynierii Srodowiska PAN, nr 11, 2002, s. 233-249.

[3] Bartoszek L., Czech D.: Podatność na degradację zbiornika zaporowego Solina. Czasopismo Inżynierii Lądowej, Środowiska i Architektury, JCEEA, vol. 61, nr 4, 2014, s. 35-53.

[4] Gałczyński Ł.: Eutrofizacja wód - problem cywilizacji. Gaz, Woda i Technika Sanitarna, nr 12, 2008, s. 34-37.

[5] Gonsiorczyk T., Casper P., Koschel R.: Phosphorus-binding forms in the sediment of an oligotrophic and an eutrophic hardwater lake of the Baltic Lake District (Germany). Water Science and Technology, vol. 37, no. 3, 1998, pp. 51-58.

[6] Gnauck A., Luther B., Heinrich R., Hoffmann A.: Modelling and simulation of phosphorus dynamics in shallow lakes. $4^{\text {th }}$ International Conference on Reservoir Limnology and Water Quality, Ceske Budejovice Czech Republic, 2002, pp. 98-101.

[7] Kajak Z:: Hydrobiologia-Limnologia. Ekosystemy wód śródlądowych. PWN, Warszawa 1998.

[8] Kentzer A.: Fosfor i jego biologicznie dostępne frakcje w osadach jezior różnej trofii. Rozprawa habilitacyjna, Wydawnictwo UMK, Toruń 2001.

[9] Koszelnik P.: Źródła i dystrybucja pierwiastków biogennych na przykładzie zespołu zbiorników zaporowych Solina-Myczkowce. Oficyna Wydawnicza Politechniki Rzeszowskiej, Rzeszów 2009.

[10] Pardo P., Rauret G., Lopez-Sanchez J.F.: Shortened screening method for phosphorus fractionation in sediments. A complementary approach to the standards, measurements and testing harmonized protocol. Analytica Chimica Acta, no. 508, 2004, pp. 201-206.

[11] Płużański A.: Nutrient loads in small mountain watersheds of the Solina reservoir. Ekol. pol., no. 38, 1990, pp. 337-354.

[12] Raport z realizacji wojewódzkiego cyklu kontrolnego pt. „Ochrona wód Zbiornika 
Solina przed zanieczyszczeniami”. Wojewódzki Inspektorat Ochrony Środowiska w Rzeszowie, Rzeszów 2013.

[13] Ruban V., Lopez-Sanchez J.F., Pardo P., Rauret G., Muntau H., Quevauviller Ph.: Development of a harmonized phosphorus extraction procedure and certification of a sediment reference material. J. Environ. Monit., no. 3, 2001, pp. 121-125.

[14] Skiba W.: San. Ocena stanu i jakości wód płynących oraz zbiornika zaporowego Solina. http://www.biblioteka.sanok.pl/www/pdf/sanocena.pdf [dostęp: 7 kwietnia 2014 r.].

[15] Stanisz A.: Przystępny kurs statystyki z wykorzystaniem programu STATISTICA na przykładach z medycyny. Tom II. Modele liniowe i nieliniowe. StatSoft Polska, Kraków 2000.

[16] Wiśniewski R.J.: Fosfor w zbiornikach zaporowych - zasilanie, kumulacja, wymiana między osadami dennymi i wodą, [w:] Zintegrowana strategia ochrony i zagospodarowania ekosystemów wodnych, W.M. Zalewski (red.). Biblioteka Monitoringu Środowiska, Łódź 1994, s. 49-60.

[17] Wiśniewski R.: Inaktywacja fosforanów w osadach dennych jako metoda redukcji symptomów eutrofizacji, [w:] Procesy biologiczne w ochronie i rekultywacji nizinnych zbiorników zaporowych, W.M. Zalewski (red.). Biblioteka Monitoringu Środowiska, Łódź 1995a, s. 189-201.

[18] Wiśniewski R.J.: Rola zasilania wewnętrznego w eutrofizacji zbiorników zaporowych, [w:] Procesy biologiczne w ochronie i rekultywacji nizinnych zbiorników zaporowych, W.M. Zalewski (red.). Biblioteka Monitoringu Środowiska, Łódź 1995b, s. 61-70.

\title{
CIRCULATION OF PHOSPHORUS BETWEEN OVERLYING WATER AND SEDIMENTS IN THE SOLINA RESERVOIR ECOSYSTEM
}

\begin{abstract}
S u m m a r y
The aim of this paper is to analyse the influence of selected parameters on the amount of phosphorus in interstitial water and the direction of its movement at the water - sediment interface in the Solina reservoir. Surface and overlying water samples as well as bottom sediment samples were collected from four stations on the Solina reservoir during the growing season of 2005 and 2006. Higher concentrations of phosphorus, iron and manganese forms, and a high $\mathrm{Fe} / \mathrm{P}$ ratio were found in the overlying water zone as compared to the surface one. Relatively low concentrations of mineral phosphorus occurred in interstitial water of the Solina reservoir sediments. The substantial variability in concentration range was due to lower levels of sediment hydration, which impedes the diffusion process of phosphate. The average content of mineral phosphorus in interstitial water of the Solina reservoir sediment was at the level corresponding to oligotrophic lakes. Good oxygenation prevailing throughout the test period, high concentrations of iron, as well as the high $\mathrm{Fe} / \mathrm{P}$ ratio in the overlying water created very favourable conditions for the precipitation and deposition of phosphate in sediments, but not for its release. Bottom sediments of the Solina reservoir had a relatively low phosphorus concentrations and a high content of iron and manganese, as well as a high $\mathrm{Fe} / \mathrm{P}$ ratio, which are the factors affecting durability of $\mathrm{Fe}-\mathrm{P}$ and $\mathrm{Mn}-\mathrm{P}$ connections in less favourable oxidation - reduction conditions. In the subsurface layers of bottom sediments, the mineral phosphorus content present in interstitial water which was deoxidised periodically, significantly depended on the amount of iron and manganese in deposits.
\end{abstract}

Keywords: mineral phosphorus, overlying water, interstitial water, bottom sediments, phosphorus fractions

Przestano do redakcji: $30.05 .2015 \mathrm{r}$.

Przyjęto do druku: 1.12.2015 r.

DOI: $10.7862 / \mathrm{rb} .2015 .93$ 